\title{
Fix Ballas Simulation to Achieve The Stability of The Shipyard Graving Dock Door
}

\author{
Oktoberty $^{1}$, Sri Pramono ${ }^{1}$, Tjokro Hadi², S Budirahardjo ${ }^{3}$, Agus Tri Wandono ${ }^{4}$ \\ ${ }^{1}$ Maritime Faculty, Universitas Ivet, Semarang, Central Java, Indonesia \\ ${ }^{2}$ Politeknik Negeri Semarang, Central Java, Indonesia \\ ${ }^{3}$ Engineering Faculty, Universitas PGRI, Semarang, Central Java, Indonesia \\ ${ }^{4}$ PT Jannata Marina Indah, Semarang, Central Java, Indonesia
}

\begin{abstract}
Indonesia's geograpycal is archipelago. As archipelago, Indonesia has been recognized world by internationally. Srategic conditions in Indonesia demand that the county is able to develop the potential of the maritime. One of the efforts in develelopment about maritime potential is one of them is manufacture model dry dock gate is stable. Dry Dock Shipyard Door Modeling is used to carry out the analyzes needed by the research and also wants to promote the use according to the needs of the field, both in terms of safety, comfort and budget in terms of operational safety. This research program aims to resolve the stability of Dry Dock doors with a length of 40.4 meters using Maxsurf and Hydromax software in analyzing estimates using intervals of $500 \mathrm{~mm}$ in length expected to produce detailed data leading to longitudinal and transverse data as asked by the process ship planning in general. The result of dry dock gate analysis with a length of $40.4 \mathrm{~m}$ meets IMO standards where ballast construction requires $54 \%$ and $68 \%$ and using ballast fix will be able to produce a GMt value of $1.693 \mathrm{~m}$ with a tide height of $10.393 \mathrm{~m}$. GMt values indicate the gate dick can remain stable and sturdy standing at the bottom of the dock when dry. when the ballast is empty, it will produce GMt 1,007, which means the dock is stable, but it is still easily broken down. These conditions govern when maintaining dry dock doors.
\end{abstract}

Keywords:- Fix Ballas Simulation, Dry Dock, Model Dry Dock, Software Maxsurf.

\section{INTRODUCTION}

Shipyard is a place to build or repair the ships [1]. Shipyard consists of permanent workshops that work on new buildings and ship repairs from a construction of heavy enough floating objects made of steel or non-steel in a place that has a large enough and deep water to float the construction, it has a certain area and works continuously throughout the year so basically a shipyard must be had [2].

Based on its activities, shipyards can be classified as; shipbuilding, exspecially for new building shipyard that is only shipbuilding build the new ships with a relatively long time, shipbuilding specially for ship reparation is a shipyard specifically doing ship repair work, both annual repair and special repair, and shipbuilding for new buildings and and repairs (combined), namely shipyards that have multiple activities, can be used for new buildings and repairs.
Based on the execution time and work in the shipyard, ship repair can be divided periodically into three times; annual surveys are conducted every 12 months, intermediates are conducted every 2.5 years, and renewal surveys are conducted every 5 years.

The main facilities for new buildings and repairs include slipway, floating dock, lifting dock and graving dock or dry dock, slipway construction consists of rails mounted on a concrete foundation such as a building berth, and a train (cradle) above it [3]. Cradle can go up and down on the rails with the help of steel cables (slink) pulled by a crane (Winch). Floating dock is a type of dock that is portable so that it can be moved. The docking process is carried out by sinking the dock and then floating on a certain water laden where the operation is assisted with filling pumps. Lift dock or ship lift is a type of dry dock that is raised and lowered. The ship's working platform from the elevator dock is a platform which is lowered into the water vertically and stopped to a certain depth. The ups and downs of the platform are assisted by a lift plane (hoist). Dry dock is a permanent structure that is entirely excavated on the ground or made by dredging and placing materials (sand, stone and concrete) next to the dock area [1].

The advantages of Graving dock compared to another types of dock are; the basic structure is longer-lived, maintenance costs are lower, there are no size restrictions, there are no concerns about the stability of the ship / dock, longitudinal pier pumping or deflection of the dock when the ship is docking, can be equipped with a gate so that it can flood from half the stern of the pier. The disadvantages of graving dock are; construction costs are high, cannot be moved, the floor is below so it is difficult in the transfering of material and personnel, difficult to enlarge, slower operations [4].

In the construction of a dry dock it is necessary to plan in detail and thoroughly, including the design of the gate / door. The base of this pool consists of reinforced concrete which has been designed by concrete piles while the door is made of steel plates whose construction is made in such a way that the door can float, where the closing door is equipped with ballast tanks used for sink and float at the time of its operation. And equipped with valves (valves) and pumps. On the lip of the door that intersects with the lip of the pool (dry dock), it is given packing of rubber to get tightness when the water in the pool is empty. 
Before the ship is loaded into the Dry Dock, the Dry Dock is filled with air with a valve installed, after the air surface in the dry dock is the same as the outer surface of the Dray Dock, the gate is opened or shifted and the ship can be put into the dry dock. With the consideration of the construction of the dry dock door, the difficulty in a variety of needs requires maximum construction and construction stability in order to obtain optimal benefits and functions.

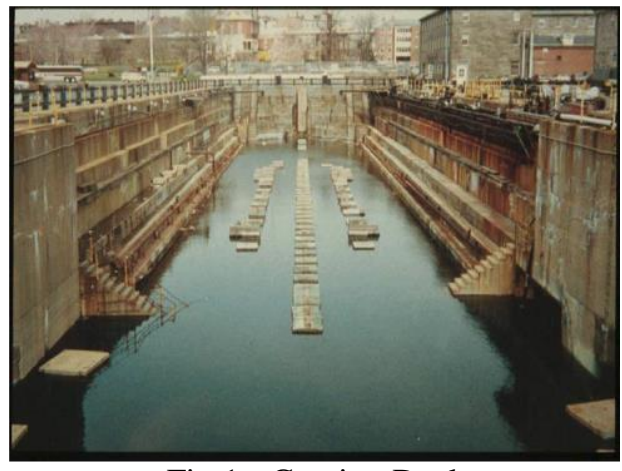

Fig 1:- Graving Dock

Source: heger Dry Dock, 2005

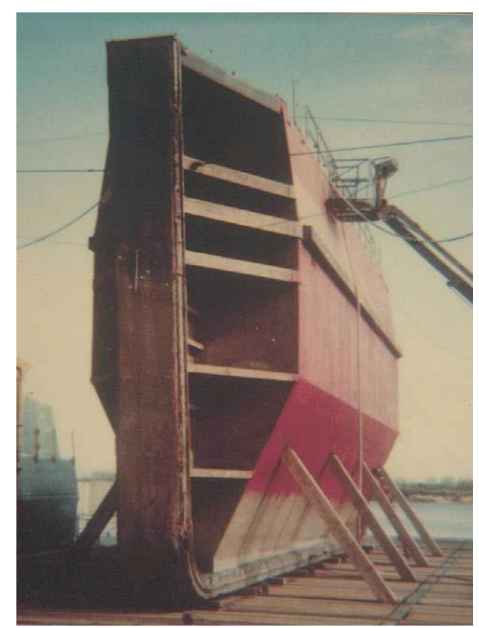

Fig 2:- Graving Dock Gate

Graving dock is a structure that is made to hold water so that it does not enter during the process of repair or shipbuilding in the graving dock. During the operational period, the graving dock gate always receives different loads depending on the ladder height and height of the ballast inside the graving dock gate tank. This burden is continuous which can result in fatigue in the structure. Therefore, it is necessary to identify the cyclical load acting on the graving dock gate structure so that structural failure during the operational period can be avoided.

The stability of a ship can be defined as the ability of a ship to return to its upright position after experiencing the tilt caused by the forces acting on it. There are 3 points that play an important role in observing the stability of a ship, namely the $G, B$ and $M$. points of gravity $G$ (center of gravity) is the resultant point of gravity for all parts of the ship including all the contents in it which presses downward; floating point B (Bouyancy) is the geometric center of the ship that is submerged in water that presses upward, and point $M$ (metacenter) is the height of the inclination angle of the ship's keel and the center point of the line that applies buoyancy and gravity [5], [6].

If $M>G$ the ship will be stable, if $M=G$ the ship becomes neutral, if $M<G$ the ship is in an unstable state. To determine the seaworthiness of a ship technically it is necessary to know the high and low (metacentri hight), GM. If the GM value is bigger the ship will become more stable. The ship is said to be seaworthy if the stability of the ship is good, the longitudinal and transverse construction is firmly mounted, the materials are made according to the rules, if the ship moves well, complete ship equipment and safety equipment according to standard, this needs to be done to produce an intact ship building, sturdy and resistant to natural phenomena that occur in the waters of the sea.

Tilt construction position analysis aims to investigate the stability of construction in the shipbuilding process with a test object called the center of gravity to find out the highest value from the metacentis point. The center of gravity's position with accurate values taken is necessary to maintain the stability of ship construction. The tilt construction analysis shown also finds the vertical distance from the G Point to the K Point accurately when the ship's construction is stable [7].

Determination of the main dimensions of the ship, the ratio of the main dimensions of the ship, and the coefficient of the shape of the ship, must be based on special considerations, because these parameters affect the nature and characteristics of the ship. To find out the characteristics of the stability of the ship in each draft can be seen in the hydrosastic table. In addition, stability is influenced by two internal and external factors. Internal factors include the construction of the building itself while external factors include the weather, waves, and storm factors .

Slant testing using ballast pendulum is not practical because it uses a lot of tools and equipment. This conventional calculation process is quite complicated, less accurate, requires high accuracy in reading the slope of the ship from the pendulum deviation to the CL line [8]. In ship design, there are currently a variety of devices that can be used to simplify ship design and have more precise and detailed results. Maxsurf is software that can be used to analyze ship stability. By entering vessel data, maxsurf will process and produce hydrostatic parameter values in the form of data tabulations and hydristatic curves [9], [10]. Maxsurf is software that can be used for risk modeling and seepage analysis [9], [11], [12]. The Maxsurf software generates vessel feasibility data [13]. Maxsurf is one of the CASD with designs using test results with a design process that is in accordance with the design development using old design samples (knowledge gained) about old designs directly, then starting old designs to produce new designs. design [14]. Other research was also carried out using the Bayestian Network algorithm to analyze the failure of the dry dock gate. 
This study is based on previous research with a dry gate dock length of 35.4 meters. This study uses a dry dock gate with a length of 40.4 meters. Increased length aims to increase stability. In previous studies had obtained good stability with leakage tests, the dry dock gate can still float with a maximum angle of 33.50 and remain floating [15].

\section{METHOD}

This study used a computer modelling method with Maxsurf and Hydromax software. Maxsurf is used to determine the hydrostatic characteristics of each ship. The tests included tank sounding, hydrostatic, simulation on three different constructions with the first condition using fixed ballast simulation and without ballast. The second simulation construction used a fixed ballast and ballast

DIMENSI FIXED BALLAST
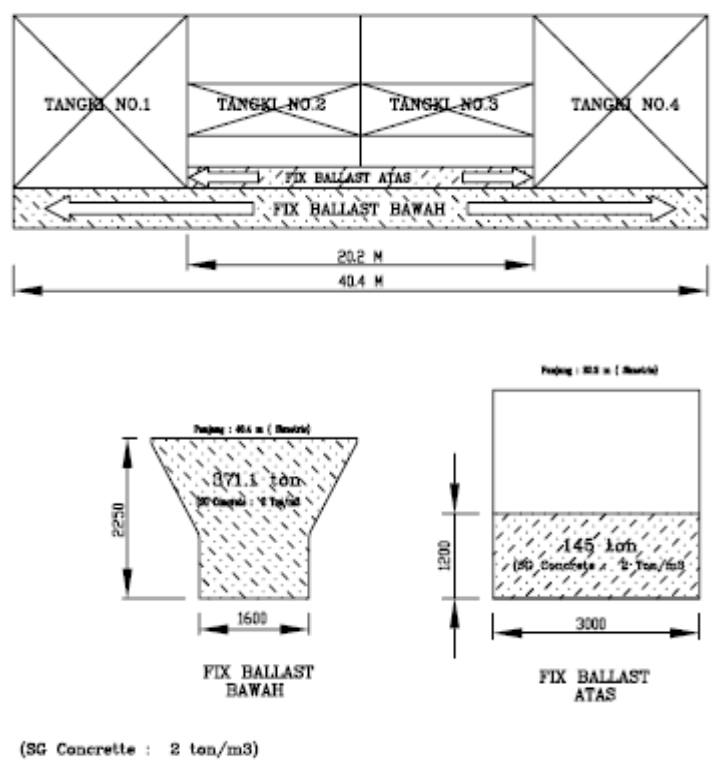

Fig 3:- Design of Graving dock simulation. Third simulation construction is without fixed ballasts, without ballasts. It also simulated leakage in the tank so that it was filled with seawater. The criteria for achieving stability used by the International Marine Organization (IMO) standard.

\section{RESULT AND DISCUSSION}

Modeling was carried out on a dry dock gate with a length of $40.4 \mathrm{~m}$, width $3 \mathrm{~m}$ with four water tanks as ballasts. High gate and fix ballas $7.4 \mathrm{~m}$ with an estimated $8.5 \mathrm{~m}$ ebb tide and an estimated $10.5 \mathrm{~m}$ tide. air Ballast fix height below $2.25 \mathrm{~m}$ and ballast height above $1.2 \mathrm{~m}$. Ballast fix weight below 371.1 tons and ballast fix above 145 tons with SG Concrette 2 tons / m3. The dry dock gate design can be seen in Figure 3.

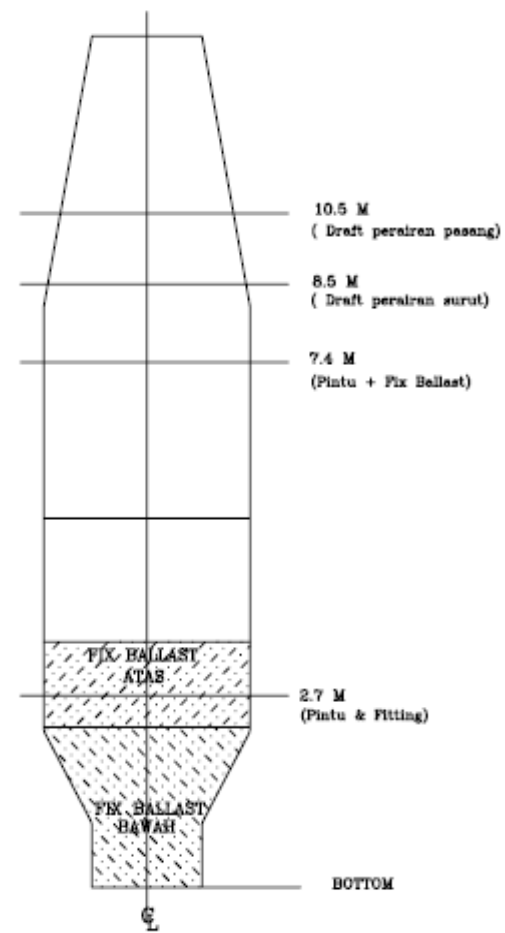

\section{A. Tank Sounding}

\begin{tabular}{|c|c|c|c|c|c|c|c|}
\hline \multirow{2}{*}{ NO } & \multirow{3}{*}{ Compartment / Storage } & \multicolumn{5}{|c|}{ Condition } \\
\cline { 3 - 8 } & & & Empty & \multicolumn{4}{|c|}{ Full Storage } \\
\cline { 3 - 8 } & & LCG & TCG & VCG & LCG & TCG & VCG \\
\cline { 3 - 8 } & & $4,032 \mathrm{~m}$ & $0 \mathrm{~m}$ & $5,215 \mathrm{~m}$ & $3,981 \mathrm{~m}$ & $0 \mathrm{~m}$ & $6,941 \mathrm{~m}$ \\
\hline 1 & NO. 1 & $13,836 \mathrm{~m}$ & $0 \mathrm{~m}$ & $5,215 \mathrm{~m}$ & $13,836 \mathrm{~m}$ & $0 \mathrm{~m}$ & $6,673 \mathrm{~m}$ \\
\hline 2 & NO.2 & $26,573 \mathrm{~m}$ & $0 \mathrm{~m}$ & $5,215 \mathrm{~m}$ & $26,573 \mathrm{~m}$ & $0 \mathrm{~m}$ & 6,673 \\
\hline 3 & NO. 3 & $36,365 \mathrm{~m}$ & $0 \mathrm{~m}$ & $2,297 \mathrm{~m}$ & $36,417 \mathrm{~m}$ & $0 \mathrm{~m}$ & $6,941 \mathrm{~m}$ \\
\hline 4 & NO. 4 & & & &
\end{tabular}

Table 1

\section{B. Hydrostatic}

Modeling is done every $0.20 \mathrm{~m}$ of immersed volume and starting from a depth of $0.20 \mathrm{~m}$ to $11 \mathrm{~m}$. The data shows that every height on the backward reference line and the upright reference line are the same or there is no slope, it shows the door in an upright position. When the draft in the middle in the elongated direction is $11 \mathrm{~m}$, the weight of the volume of fluid displaced by the body of the object being blown is 1,166 tons with a block coefficient of 0.900 and the location of LCB is 0 from the center of the door towards the elongated. The amount of weight of the fluid displaced by the sinking of the door, at the rear, the front of 
the coefficient of the block and LCB has decreased according to the design at the height of the center until the position of the door immersion $1 \mathrm{~m}$ vertically by 58.1 tons, at the rear, the front $1 \mathrm{~m}$, the coefficient block 0,940 , and LCB $0,001 \mathrm{~m}$ from the middle of the door towards the elongated.

The distance of the center of gravity of the door to the metacenter point in the highest transverse direction is 2,903 $\mathrm{m}$ when the door is immersed as deep as $11 \mathrm{~m}$, this condition is the most stable condition. The center of gravity point distance to the metacenter point in the transverse direction decreases according to the draft height. The distance of the center of gravity to the metacenter point in the transverse direction has a value of $0.054 \mathrm{~m}$ at the time of the draft at $5.5 \mathrm{~m}$, the condition is that the values of $\mathrm{G}$ and $\mathbf{M}$ are close together, so that the door is still in an upright position, but is easy to lay down. By the time the draft reached $5.25 \mathrm{~m}$, the center of gravity to the metacenter point in the transverse direction was negative, amounting to $-0.67 \mathrm{~m}$, indicating the door was unstable. Value The center of gravity for the metacenter point in the lowest transverse direction is in the $1 \mathrm{~m}$ draft with a value of $-2.325 \mathrm{~m}$.

\section{Tank Condition With Fixed Ballast and Without Balast}

A condition without ballast means that the tank is not filled with water. The weight of the door and its fittings is 226 tons, Fixed ballast is above 145 tons, Ballast remains under 371.7 tons, so the total weight is 743 tons. The LCG of the door and base fittings are in the position of $20.2 \mathrm{~m}$, and the upper and lower fixed ballasts are in the position of $20.2 \mathrm{~m}$, while compartment 1 is $5.529 \mathrm{~m}$, compartment 2 is $15.165 \mathrm{~m}$, compartment 3 is 25.240 and compartment 4 is $34.865 \mathrm{~m}$. The door and VCG construction are at $6.5 \mathrm{~m}$, ballast remains above $2.75 \mathrm{~m}$, Ballast remains below 1.06 $\mathrm{m}$, while VCG compartment 1 is $6.892 \mathrm{~m}$, compartment 2 is $6.673 \mathrm{~m}$, compartment 3 is $6.673 \mathrm{~m}$ and compatement 4 is at $6.89 \mathrm{~m}$. The LCG gate is in position $20.2 \mathrm{~m}$ or in the middle with VCG $3.045 \mathrm{~m}$ and water VCG 3.045 and TCG and FSM $0 \mathrm{~m}$

The condition of the gate with ballast and not filled with water produces GMt in the position of 1,006 m. This results in a gate that can float stable but is easily broken. This condition is used to make the gate repair process.

\begin{tabular}{|c|c|c|c|c|c|c|}
\hline Item Name & Q'ty & Weight(ton) & LCG & VCG & TCG & FSM \\
\hline Konstr.Pintu \& Fittings & 1 & 226.0 & 20.200 & 6.500 & 0.000 & 0.000 \\
\hline Fixed Ballastatas & 1 & 145.0 & 20.200 & 2.750 & 0.000 & 0.000 \\
\hline Fixed ball as tbawah & 1 & 371.7 & 20.200 & 1.060 & 0.000 & 0.000 \\
\hline Tank1T & $0 \%$ & 0.0000 & 5.529 & 6.892 & 0.000 & 0.000 \\
\hline Tank4T & $0 \%$ & 0.0000 & 34.865 & 6.890 & 0.000 & 0.000 \\
\hline Tank2T & $0 \%$ & 0.0000 & 15.165 & 6.673 & 0.000 & 0.000 \\
\hline Tank3T & $0 \%$ & 0.0000 & 25.240 & 6.673 & 0.000 & 0.000 \\
\hline Total Weight & & 743 & 20.200 & 3.045 & 0.000 & 0.000 \\
\hline & & & F Scorr.=0 & \multicolumn{2}{c|}{ VCG fluid=3.045 } \\
\hline
\end{tabular}

Table 2:- Data of stability with fix ballast and without ballast

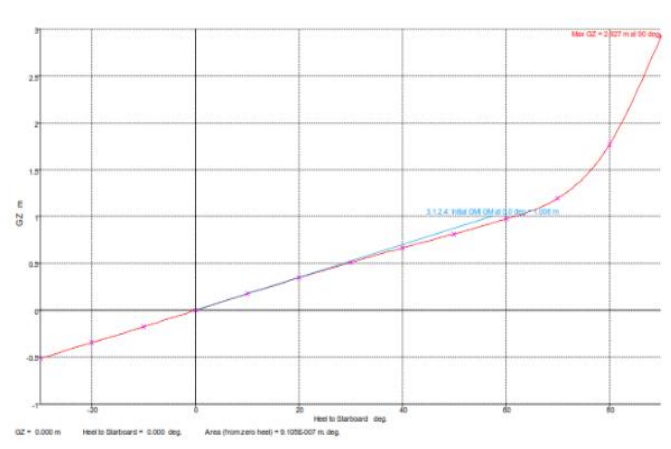

Fig 4:- Graph of stability with fixed ballast and without ballast

\section{Tank Conditions with Fixed Ballasts \& Ballasts}

The weight of the door and its equipment is 226 tons, Fixed ballast above 146 tons, ballast remains under 371.7 tons, tank weighs 179 tons, tank 246.56 tons, tank 3 72ton, tank 479 tons, so that the total weight is 1045 tons. LCG doors and bed fittings are in position $20.2 \mathrm{~m}$, and ballast remains top and bottom in position $20.2 \mathrm{~m}$, while Tank 1 is $5,610 \mathrm{~m}$, tank 2 is $15,165 \mathrm{~m}$, tank 3 is $25,240 \mathrm{~m}$ and tank 4 is $34,783 \mathrm{~m}$. The door and VCG construction are at $6.5 \mathrm{~m}$, ballast remains above $2.75 \mathrm{~m}$, Ballast remains below 1.06 $\mathrm{m}$, while VCG 1 compartment is $3,898 \mathrm{~m}$, Tank 2 is 6,363 $\mathrm{m}$, tank 3 is $6,362 \mathrm{~m}$ and tank 4 at $3,893 \mathrm{~m}$. LCG gate is in the position of $20.2 \mathrm{~m}$ or in the middle with $3,631 \mathrm{~m} \mathrm{VCG}$ and 3,698 VCG water and $0 \mathrm{~m} \mathrm{TCG}$ and FSM. This condition causes an FS correction of 0.067 .

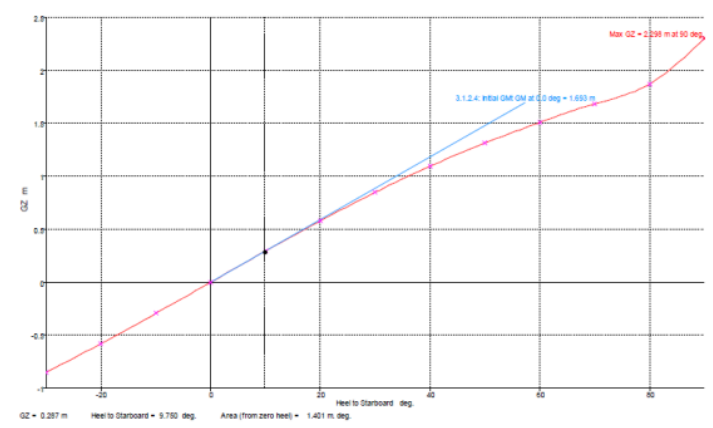

Fig 5:- Graph of stability gate use fixed balalst and without ballast 
When the gate with fix ballast and ballast filled with water as much as $54 \%$ produces GMt $1,924 \mathrm{M}$ with water height of $11,357 \mathrm{M}$. In this condition, the door can stand upright

\section{E. Tank Conditions Without Fixed Ballasts \& Ballasts}

The weight of the door and its equipment is 226 tons. The LCG of the door and fittings are in position $20.2 \mathrm{~m}$, and the upper and lower fixed ballast are in position 20.2 $\mathrm{m}$, while compartment 1 is $5,529 \mathrm{~m}$, compartment 2 is $15,165 \mathrm{~m}$, compartment 3 is $25.24 \mathrm{~m}$ and compartment 4 is $34,865 \mathrm{~m}$. The door and equipment have a VCG of $6.5 \mathrm{~m}$, the upper fixed ballast has a VCG of $2.75 \mathrm{~m}$, the ballast remains at the bottom of the VCG value of $1.06 \mathrm{~m}$, while the VCG in compartment 1 is $6.892 \mathrm{~m}$, compartment 2 the CVG is $6.673 \mathrm{~m}$, compartment 3 CVG $6,673 \mathrm{~m}$ and $4 \mathrm{CVG}$ $6,890 \mathrm{~m}$ compartments.

If the door without ballast is fixed and without ballast or is not filled with water, it will produce a GMt value of $4,698 \mathrm{~m}$ with a water level of $2,685 \mathrm{~m}$. This condition means the door is in an unstable position.

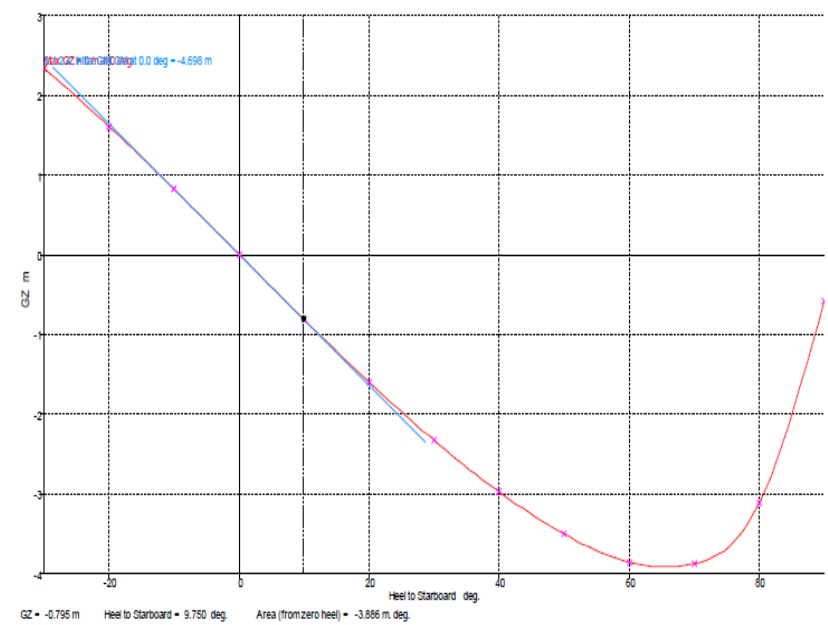

Fig 6:- Gate stability graph with fixed ballasts and without ballasts

\section{F. Damage Condition}

The last modeling is to simulate the compartment which has the largest volume and is filled with water until full, causing the gate to tilt at $23.8 \mathrm{o}$ and is still floating. This means that despite leakage and sinking, the gate remains in stable condition.

A gate with a length of $40.4 \mathrm{~m}$ is more stable than a gate with a length of $35.4 \mathrm{~m}$. This can be seen from the GMt value. The GMt gate value in this study increased to $1,007 \mathrm{~m}$ when the ballast was empty or not filled with water. When filled with GMt water it reached $2.741 \mathrm{~m}$ or higher than the previous study with a value of $1,924 \mathrm{~m}$ even though the condition was still in stable condition. Likewise, when a leak occurs, the gate only tilts 23.8 o to the elongated and still floats.

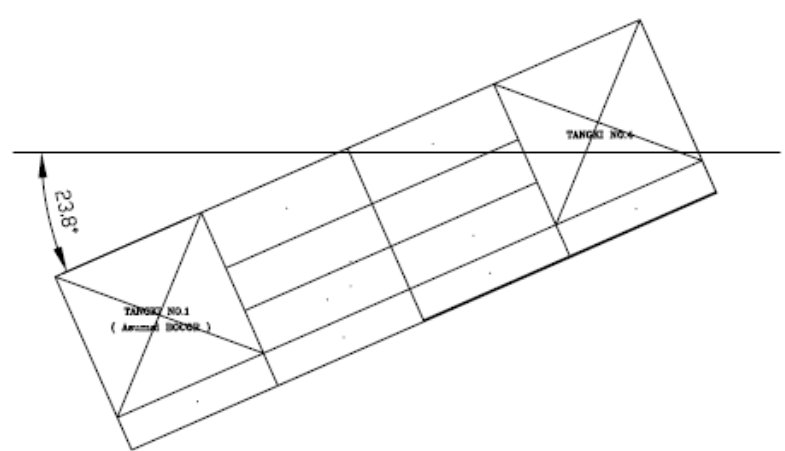

Fig 7:- The condition of the gate when a leak occurs

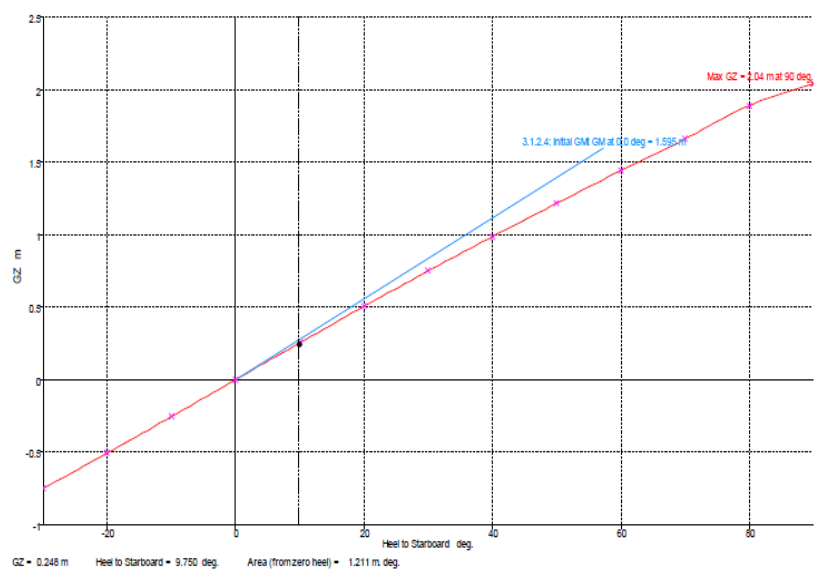

Fig 8:- Gate stability graph when a leak occurs

\section{CONCLUSIONS}

The results of modeling on the dry dock gate which has a width of $40.4 \mathrm{~m}$ and has four tanks with capacities of $114,371 \mathrm{~m} 3,112,004 \mathrm{~m} 3,112,243 \mathrm{~m} 3$ and 114,534m 3 have good stability which can be seen from the GMT value that can be achieved over $0.15 \mathrm{~m}$ and has met the stability standards and has an ideal compartment division because it has conditions that are planned to be positioned to sleep at the time of repair. This can be seen based on the value of GMY which can be conditioned to a negative value by disposing ballast water.

\section{REFERENCES}

[1]. Storch R L Hammon C P Bunch H M and Moore R C, 1995, Ship Production, Society of Naval Architects and Marine Engineers. Jersey City.

[2]. Hanley T Sowder A M Palmer C A and Weiss R L, 2016 Teaching Laboratory Management Principles and Practices Through Mentorship and Graduated Responsibility: The Assistant Medical Directorship Acad. Pathol. 3, 1 p. 1-10.

[3]. Najafi-Jilani A and Naghavi A, 2009 Numerical modeling of seawater flow through the flooding system of dry docks Int. J. Nav. Archit. Ocean Eng. 1, 2 p. 57-63.

[4]. Heger R, 2005 Dockmaster training manual . 
[5]. Hind J A, 1982 Stability and Trim of Fishing Vessels and Other Small Ships Farnham: Surrey: Fishing News Books.

[6]. Hind J A, 1967 Trim and Stability of Fishing Vessel London: Fishing News.

[7]. Pangalila F, 2010 Stabilitas Statis Kapal Ikan Tipe Lambut Tersanjung yang Berpangkalan di Pelabuhan Perikanan Samudera Tembaga Kota Bitung Propinsi Sulawesi Utara J. Perikan. dan Kelaut. Trop 6, 1 p. 149-155.

[8]. Rachman I, 2014 Identiffikasi Garis Stabilitas Melintang Kapal Melalui Percobaan Kemiringan Menggunakan Delphi Berbasis Arduino Transmisi 16, 3.

[9]. Krismawati F D Zakki A F and Manik P, 2014 Perancangan Bangunan Apung dan Keramba dengan Sistem Modular Ponton Berbahan Ferosemen J. Tek. Perkapalan 3, 3 p. 66-73.

[10]. Palembang S Luasunaung A and Pangalila F P T, 2013 Kajian rancang bangun kapal ikan fibreglass multifungsi 13 GT di galangan kapal CV Cipta Bahari Nusantara Minahasa Sulawesi Utara J. Ilmu dan Teknol. Perikan. Tangkap 1, 3 p. 87-92.

[11]. Windyandari A and Wahyudi D, 2001 Methodology of The Hybrid Propulsion System ( DMP \& DEP ) for Trimaran Type Fast Patrol Boat Kapal 8, 3 p. 161172.

[12]. Charizzaka A Aria I K Utama P and Putranto T, 2016 Analisis Pengikatan dan Gerakan Pada Dok Apung Akibat Gaya Luar dengan Variasi Desain Pengikatan di Perairan Dangkal Terbuka J. Tek. ITS 5, 2 p. $217-$ 222.

[13]. Soeroso H and Setiawan B T, 2013 Perencanaan Ruang Muat Ikan Hidup pada Kapal Penangkap Ikan di TPI Brondong Lamongan Jawa Timur Kapal 10, 1 p. $8-12$.

[14]. Hadi E sasmito, 2010 Perancangan Kapal Ikan Katamaran Dengan Penggerak Mesin dan Layar di Kabupaten Rembang Kapal 7, 3.

[15]. Oktoberty Widiyanto Sasono E J A S P and Wandono A T, 2018 Dry dock gate stability modelling J. Phys. Conf. Ser. 983, 1 p. 12036. 